https://doi.org/10.12797/MOaP.23.2017.38.05

Anna Jankowska ${ }^{1}$

Jagiellonian University in Kraków/ Universitat Autònoma de Barcelona anna.m.jankowska@uj.edu.pl / anna.jankowska@uab.cat

\title{
Blended Learning in Audio Description Training
}

\section{Introduction}

In recent years we have witnessed an audio description (AD) boom both in research and in professional practice, especially when it comes to film audio description. This entails an increase in the demand for trained AD professionals. $\mathrm{AD}$ training is now provided in academic and non-academic environments in various formats: within graduate, postgraduate studies or vocational training courses, as part of AVT training or as standalone modules [Jankowska, 2015; Reviers, 2016]. Whatever the form, they all have one thing in common: the lack of a competence model they can draw from. There is currently no systematic and comprehensive description of skills and abilities needed to become a successful audio describer. Many scholars and researchers [Orero, 2005; Matamala, Orero, 2007; Remael, Vercauteren, 2007; Utray, Pereira, Orero, 2009; Jankowska, 2015] suggest that a professional profile of the describer is lacking. This gap might soon be filled by the outcomes of the ongoing $\mathrm{ADLAB} \mathrm{PRO}^{2}$ project, the aim of which is to create a professional profile of the yet little known professional figure.

1 This work has been supported by the research grant "ECR transfer in audio description" no. 1311/MOB/IV/2015/0 of the Polish Ministry of Science and Higher Education for the years 2016-2019 and by the European Commission under the Erasmus+ programme research grant 2016-1-IT02-KA203-024311.

2 http://ec.europa.eu/programmes/erasmus-plus/projects/eplus-project-details-page/? nodeRef=workspace://SpacesStore/fd594781-ccfb-4118-ae90-a15441abb9c9 and www.adlabproject.eu 
In light of that, I would firstly like to explain what is not the aim of this article. I do not intend to create a comprehensive framework of skills and competencies of a successful audio describer. Neither do I hope to propose an exhaustive teaching methodology. My intention is to share my experiences in teaching AD in academia since little has been published on the topic [Matamala, Orero, 2007; Snyder, 2007, 2014; Sadowska, 2014; Fryer, 2016]. This article should then be regarded as a practice report.

Most of this article's content draws on a module in audio description taught within the audiovisual translation course at the MA course in Translation and Intercultural Communication at the Chair for Translation Studies and Intercultural Communication at the Jagiellonian University in Krakow. However, much of this content exploits my previous training experience: I have been teaching $\mathrm{AD}$ at the Jagiellonian University since 2009 (MA courses and short vocational courses), as well as delivering training to broadcasters and the Seventh Sense Foundation - an NGO established by my students and myself in 2011 in order to put theory into practice. The latter was and is an invaluable experience for both my research and teaching.

\section{Pedagogical approach}

Before we move onto discussing the course design and activities, a short explanation on the pedagogical approach is needed. In my approach to teaching I choose not to give students readymade solutions, but to give them means, knowledge and freedom to create tools of their own. I hope that this will allow them to find solutions to the uncountable challenges they most certainly will stumble across while performing their job.

The content and the design of the course is based on my experience as a researcher but also as a practising describer and AD producer responsible for the entire process of producing $\mathrm{AD}$ and delivering it to clients i.e. commanding AD scripts and recordings and assuring their quality and a reasonable workflow. This double background influences my pedagogical approach. I am deeply convinced that audio describers' training should combine theory and practice. On the one hand, introducing theory in an AD classroom can help future describers overcome $\mathrm{AD}$ crisis points without having to reinvent the wheel since research 
conducted in AD describes actual practices [Matamala, Rami, 2009; Orero-Clavero, 2012; Chmiel, Mazur, 2014; Maszerowska, Matamala, Orero, 2014; Jankowska, Zabrocka, 2016]. On the other hand, theory can give students freedom of experimenting with non-standard approaches as much of $\mathrm{AD}$ research presents the results of experiments involving reception studies of avant-garde AD solutions - e.g. text-to-speech audio description [Szarkowska, Jankowska, 2012], amateur, creative or emotional audio description [Fryer, Freeman, 2013; Szarkowska, Wasylczyk, 2014; Ramos Caro, 2015, 2016; Walczak, 2017; Walczak, Fryer, 2017], translation of audio description scripts [Jankowska, 2015] strategies for dealing with different aspects of description [Chmiel, Mazur, 2014, 2016; Maszerowska, Matamala, Orero, 2014; Szarkowska, Jankowska, 2015; Jankowska, Szarkowska, 2016]. Theory alone is not enough - it is hands-on-training that requires students to find non-theoretical solutions to problems that need to be fixed 'here and now'.

As already explained, the content of the module is based on my professional experience. When it comes to teaching methodology, it is not based on any particular framework. The final outcome is a result of trialand-error of what I believed would be attractive, effective and efficient. The general approach I follow includes some deductive learning but relies heavily on inductive learning where students are encouraged to come to conclusions on their own. Generally speaking, my approach can be placed within Laurillard's [Laurillard, 2012: 96] framework of types of learning which includes learning through acquisition, inquiry, practice, production, discussion and collaboration. Summing up, I would like to think that I try to train students into professionals with whom I would like to work with in the future.

\section{Module design}

The thirty-hour module was part of a larger (120 hours) course in AVT taught to students enrolled in the MA course in Translation Studies at the Chair for Translation Studies and Intercultural Communication at the Jagiellonian University in Krakow. The AD module was originally taught for a period of fifteen weeks to students who had previously completed modules in voice-over, subtitling and subtitling for the deaf and hard of hearing. 
The module was organized in eight thematic units and taught by means of blended learning - combining on-line activities realized through Moodle (18 hours) with occasional face-to-face meetings (12 in 3 four-hour sessions) that took place at the beginning, in the middle and towards the end of the semester. Face-to-face meetings were generally thought as complimentary to the on-line modules, allowing to further elaborate on issues tackled on-line, and carry out activities impossible or difficult to perform in a digital environment. Additionally, interested students could participate in real-life tasks that consisted in preparing AD for a film festival. All the units had a similar structure and involved the following activities:

a) Introduction: each unit started with a short, written introduction outlining the work to be done and explaining the purpose of the activities.

b) Lecture: for the purpose of the module, two types of lectures were used: (1) live lectures delivered in person during the face-to-face sessions and (2) pre-recorded lectures. The pre-recorded lectures were mostly recorded ${ }^{3}$ by myself in such way that students would see the Power Point presentation with bullet points, graphs etc. and hear my voice elaborating on the presented concepts. Online lectures by other scholars ${ }^{4}$ were included whenever possible and available.

c) Reading assignment: all units included the reading of academic papers or book chapters. The aim of the reading activities was to give students an overview of the state of the art in AD research and potential ideas regarding their MA projects, but also to give them leverage in professional practice.

d) Quiz: quizzes were provided in all units as means of partial assessment. Quizzes were based on lectures and reading assignments and consisted of various types of questions e.g. multiple choice, true/ false, short or long answer.

e) Discussion: discussions were carried out by means of online forums or were held in class. Whenever the latter was the case, students were usually given time to discuss selected subjects in pairs or teams

3 For recording and editing I used Movavi Screen Capture Studio and Sony Vegas commercial software.

4 http://accessguide.tv/course/. 
and only then present their arguments to the rest of the group. This was done to create a more intimate and comfortable environment in which students could share their thoughts freely. Discussions were moderated by myself, however most of the time I tried to act as 'the devil's advocate' to stimulate the discussion and encourage students to find arguments that would support and defend their viewpoints.

f) Practical tasks: practical tasks took many forms e.g. presentations, reports as well as AD drafting. In most cases, the proposed activities could be carried out individually or in pairs/teams; however, team work was given priority. Firstly, to enable students to develop team working skills (i.e. collaboration, coordination, critical thinking, dependability, group decisions, leadership, management, responsibility, receiving feedback, sharing credit) that will be needed in any project they choose to engage into in their professional life. Secondly, because of its positive influence on classroom dynamics. Whenever students engaged in team activities, recreation of real-life conditions was one of the aims. This was achieved by assuming roles (e.g. project manager, audio describer, proof reader etc.) and implementing professional tools and workflows such as co-working cloud based solutions (e.g. Google Drive) and productivity tools for project, task and time management (e.g. Asana).

\section{Module content}

The majority of the activities presented subsequently were developed by myself and tested in previous courses. Some of them were inspired by activities proposed by other AD or AVT scholars [Matamala, Orero, 2007; Franco, Matamala, Orero, 2010; Chaume Varela, 2012; Sadowska, 2014; Fryer, 2016]. Others were designed especially for this course due to its significant on-line component. The teaching materials (video and $\mathrm{AD}$ scripts/recordings) used were either produced specifically for this module, obtained from publicly available sources or from my own repository based on research or professional practice. Activities and solutions presented here draw from the original course. Possible modifications and changes are discussed in subchapter 6 . 


\subsection{Unit 1 - Accessibility: general concept}

In Unit 1 students learned about accessibility - its definitions and different viewpoints on disability and impairment. Basic notions were introduced in lectures as well as in reading assignments followed by an online quiz. Students were also asked to watch four videos reporting on different accessibility initiatives in Poland. Videos involved interviews with accessibility providers but also with its users. The purpose of this activity was twofold: to raise awareness and sensitize students but also to show them how valued and life-changing accessibility is for those who depend on it. In other words, to develop a skill that Orero (2005) calls "commitment to access for people with disabilities."

\section{Table 1. Unit 1 - theoretical introduction}

\begin{tabular}{|l|l|}
\hline Unit 1 & Accessibility: general concept. \\
\hline Lecture & $\begin{array}{l}\text { Accessibility: general concept. } \\
\text { Lecture by Pilar Orero “Introduction to accessibility" (http://ac- } \\
\text { cessguide.tv/course/). }\end{array}$ \\
\hline $\begin{array}{l}\text { Reading } \\
\text { assignment }\end{array}$ & $\begin{array}{l}\text { Greco, G.M. (2014), “On Accessibility as a Human Right, } \\
\text { with an Application to Media Accessibility", in: Matamala A., } \\
\text { Orero, P. (eds.), Palgrave Studies in Translating and Interpret- } \\
\text { ing. Researching Audio Description. New Approaches, Palgrave } \\
\text { Mcmillan, London, pp. 11-33. } \\
\text { Ellis, G. (2014), “Impairment and Disability: Challenging } \\
\text { Concepts of 'Normality"', in: Matamala A., Orero, P. (eds.), } \\
\text { Palgrave Studies in Translating and Interpreting. Research- } \\
\text { ing Audio Description. New Approaches, Palgrave Mcmillan, } \\
\text { London, pp. 35-45. }\end{array}$ \\
\hline Quiz & $\begin{array}{l}\text { Online multiple choice quiz based on the lectures and the read- } \\
\text { ing assignment. }\end{array}$ \\
\hline $\begin{array}{l}\text { Additional } \\
\text { materials }\end{array}$ & Video clips showing different accessibility initiatives in Poland. \\
\hline
\end{tabular}

When it comes to practical activities, their main goal was to sensitize students toward accessibility. Students were asked to engage in a discussion on disability (Activity 1.1) and to draft their own definitions of accessibility (Activity 1.2), based on both the materials provided in the unit and their personal experience. 
Table 2. Unit 1 - practical tasks

\begin{tabular}{|l|l|}
\hline Activity 1.1 & $\begin{array}{l}\text { Discussion: In your opinion what would be the best way to call } \\
\text { people with impairments in Polish? Why? }\end{array}$ \\
\hline Activity 1.2 & $\begin{array}{l}\text { Written assignment: Based on what you learned in this Unit and } \\
\text { your personal experience please draft a definition of accessibil- } \\
\text { ity (max. 150 words). }\end{array}$ \\
\hline
\end{tabular}

\subsection{Unit 2 - Accessibility: awareness raising and regulations}

In Unit 2 students learned about international (e.g. UN Convention of Persons with Disabilities, European Accessibility Act) and national regulations regarding accessibility. They also learned about the current situation in the EU and Poland as far as audio description services are concerned. The main aim of this unit was to raise students' awareness of availability of accessibility services and challenges that still need to be overcome.

\section{Table 3. Unit 2 - theoretical introduction}

\begin{tabular}{|l|l|}
\hline Unit 2 & Accessibility: awareness raising and regulations. \\
\hline Lecture & $\begin{array}{l}\text { Legal regulation and current state of accessibility services in } \\
\text { Poland. } \\
\text { Lectures (video recordings) by Pilar Orero: “'Unit 1.2: Raising } \\
\text { Awareness' and 'Unit 1.3: Laws and Regulations'; accessibility” } \\
\text { (http://accessguide.tv/course/). }\end{array}$ \\
\hline Reading & $\begin{array}{l}\text { Reviers, N. (2016), “Audio description services in Europe: an } \\
\text { update”, Jostrans, 26, pp. 232-247. }\end{array}$ \\
\hline Quiz & $\begin{array}{l}\text { Online multiple choice quiz based on the lectures and the read- } \\
\text { ing assignment. }\end{array}$ \\
\hline
\end{tabular}

As part of practical tasks in Unit 2 students were asked to engage in a discussion on the availability of accessibility in Poland (Activity 2.1) and to carry out small scale research (Activity 2.2) on accessibility in the United Kingdom or any other country they might choose. The UK was pointed to purposefully since it is the pioneer in the world as far as accessibility is concerned and information is easily available on the Internet. 
Table 4. Unit 2 - practical tasks

\begin{tabular}{|l|l|}
\hline Activity 2.1 & $\begin{array}{l}\text { Discussion: Please imagine that you are a blind person and try } \\
\text { to find information about accessible TV programmes, cinemas, } \\
\text { museums and theatres. How easy was it? Would you improve } \\
\text { the way information about accessibility is provided? How? }\end{array}$ \\
\hline Activity 2.2 & $\begin{array}{l}\text { Written assignment: Please carry out small scale research and } \\
\text { write a short report (250-500 words) on accessibility legisla- } \\
\text { tion in the UK or any other country (how much AD, SDH and } \\
\text { sign language is legally required) and try to find the data of how } \\
\text { much accessibility is actually provided. You can consider public } \\
\text { and private broadcasters, VOD services as well as DVD and } \\
\text { cinema distribution. }\end{array}$ \\
\hline
\end{tabular}

\subsection{UNIT 3: Introduction to audio description}

From the theoretical point of view, Unit 3 discussed various definitions of $\mathrm{AD}$ and presented its history and development from the perspective of the UK, US and Poland.

Table 5. Unit 3 - theoretical introduction

\begin{tabular}{|l|l|}
\hline Unit 3 & Introduction to audio description. \\
\hline Lecture & Audio description: history and development. \\
\hline Reading & $\begin{array}{l}\text { Jankowska, A. (2015), Translating audio description scripts: } \\
\text { translation as a new strategy of creating audio description, } \\
\text { Peter Lang, Frankfurt am Main-Berlin -Bern -Bruxelles-Ox- } \\
\text { ford-Wien, pp. 25-37. } \\
\text { Chmiel, A., Mazur, I. (2014), Audiodeskrypcja, WA UAM, } \\
\text { Poznan, pp. 1-6. }\end{array}$ \\
\hline Quiz & $\begin{array}{l}\text { Online multiple choice quiz based on the lecture and the reading } \\
\text { assignment. }\end{array}$ \\
\hline
\end{tabular}

The aim of the practical activities in Unit 3 was to give students their first insight into the challenges of AD drafting. This was achieved by allowing students to reflect upon the effect of different AD strategies and experimenting with accepting feedback and defending their standpoint. In Activity 3.1 students were asked to listen to descriptions and to draw pictures based on them. They were given two recorded descriptions of one, very schematic picture. Description 1 was very detailed but chaotic. 
Description 2 was very imprecise but well structured. Following that - in Activity 3.2 - we held a discussion on this experience. Later - in Activity 3.3 - students were asked to prepare their own descriptions of schematic pictures. There were two different pictures and students were divided in two groups. Students from Group 1 (individually) prepared descriptions of Picture 1 and students from Group 2 of Picture 2. In Activity 3.4 pairs were formed - one student from Group 1 and one student from Group 2. Each pair was asked to read and draw their descriptions. In Activity 3.5 students were asked to discuss their experience of drawing and they prepared the final versions of the descriptions based on that review. Finally in Activity 3.6 - in a class discussion - we reviewed the changes made in the descriptions.

Table 6. Unit 3 - practical tasks

\begin{tabular}{|l|l|}
\hline Activity 3.1 & $\begin{array}{l}\text { Drawing assignment: Listen to two descriptions and draw } \\
\text { pictures based on them. First listen to Description 1 and submit } \\
\text { your drawing. Only after you have submitted Drawing 1 will } \\
\text { you be able to access Description 2. Listen to Description 2 and } \\
\text { submit your drawing. }\end{array}$ \\
\hline Activity 3.2 & $\begin{array}{l}\text { Discussion: Look at the pictures you prepared and at the } \\
\text { pictures your classmates prepared. How easy was it to draw? } \\
\text { Which description was easier to follow? Why? }\end{array}$ \\
\hline Activity 3.3 & $\begin{array}{l}\text { Written assignment: Drawing on your experiences from the } \\
\text { previous activities please prepare a description of the attached } \\
\text { drawing. }\end{array}$ \\
\hline Activity 3.4 & $\begin{array}{l}\text { Pair discussion: Read the description you prepared to your } \\
\text { classmate and ask them to draw the picture you described. Do } \\
\text { the same for their description. Look at the pictures - are your } \\
\text { drawings similar to the originals? How easy/difficult was it to } \\
\text { draw? What helped you? What didn't? }\end{array}$ \\
\hline Activity 3.5 & $\begin{array}{l}\text { Pair work: Review your descriptions together with your class- } \\
\text { mate and prepare their final versions. }\end{array}$ \\
\hline Activity 3.6 & Discussion: What did you change in your descriptions and why? \\
\hline
\end{tabular}

\subsection{UNIT 4: Text editing}

AD drafting requires many skills. Editing a text - just as in the case of any AVT - is an important one of them. In Poland, AD is mostly recorded in professional studios by voice-talents. To facilitate the recording, 
describers are asked to time code and segment the script and to include symbols that help the voice-talents read as smoothly as possible. Unit 5 aimed at training students in those skills. In the theoretical part students were briefly familiarized with various conventions of AD script editing since AD scripts may come in different formats that vary from country to country, from describer to describer and from client to client. Since as for now, information on $\mathrm{AD}$ editing conventions is rather fragmented and usually tackled briefly while discussing content related issues [Szymańska, Strzymiński, 2010; Żórawska et al., 2011; Chmiel, Mazur, 2014; Remael, Reviers, Vercauteren, 2014; Fryer, 2016] internal style guide of the Seventh Sense Foundation was introduced and discussed in detail and adopted as a delivery standard for course assignments.

Table 7. Unit 4 - theoretical introduction

\begin{tabular}{|l|l|}
\hline Unit 4 & Text editing: segmentation and symbols. \\
\hline Lecture & AD Editing Guidelines. \\
\hline Quiz & Online multiple choice quiz based on the lecture. \\
\hline
\end{tabular}

There was only one practical activity in Unit 4 and it consisted in editing (segmentation and time coding included) an unformatted AD script according to the discussed and adopted style guide.

Table 8. Unit 4 - practical tasks

\begin{tabular}{|l|l}
\hline Activity 4.1 & $\begin{array}{l}\text { Individual work: } \\
\text { style guide discussed in class. }\end{array}$
\end{tabular}

\subsection{UNIT 5: Translation vs. writing}

There are currently three strategies for creating descriptions: team script drafting, individual script drafting or interlingual translation of scripts [Jankowska, 2015]. Translation of AD scripts can be used as an efficient tool for training, since it gives students the opportunity to analyse and become familiarized with different scripts before they are asked to write one on their own ADs. In Unit 5 AD translation was also used to sensitize students towards the needs of blind audiences. As in the previous 
units, a theoretical introduction was achieved through lecture, reading assignment and a quiz.

Table 9. Unit 5 - theoretical introduction

\begin{tabular}{|l|l|}
\hline Unit 5 & Text editing: segmentation and symbols. \\
\hline Lecture & “AD drafting process.” \\
\hline Reading & $\begin{array}{l}\text { Benecke, B. (2004), “Audio description", Meta, 49(1), } \\
\text { pp. 78-80. } \\
\text { Jankowska, A. (2015), Translating audio description scripts: } \\
\text { translation as a new strategy of creating audio description, } \\
\text { Peter Lang, Frankfurt am Main-Berlin-Bern-Bruxelles-Ox- } \\
\text { ford-Wien, pp. 44-50. } \\
\text { Jankowska, A. (2014), “Thumaczenie jako alternatywna metoda } \\
\text { tworzenia audiodeskrypcji”, Przektadaniec, 28, pp. 23-38. }\end{array}$ \\
\hline Quiz & $\begin{array}{l}\text { Online multiple choice quiz based on the lecture and the reading } \\
\text { assignment. }\end{array}$ \\
\hline
\end{tabular}

In Activity 5.1 students were asked to see six short film clips (ca. $1 \mathrm{~min}$ ) and to read descriptions that were prepared for them. There were two descriptions for each clip: one written by a Polish audio describer and one translated from English. Students were then asked to vote for their preferred description of each scene. Only after the vote was completed students learned that their preferences were similar to those of sighted people who completed the same procedure in a scientific experiment but different to the preferences of the blind and partially sighted participants of the same experiment. A discussion about these discrepancies and differences in translated and non-translated scripts followed Activity 5.2. Then in Activity 5.3 students were asked to draft and translate (from English into Polish) AD scripts for two short clips. They were divided into two groups. Group 1 first drafted the AD to Clip A and then translated the AD to Clip B. Group 2 first translated the AD to Clip B and then drafted the AD to Clip A. This activity was followed by a discussion (Activity 5.4) on the discrepancies between the scripts. The differences were discussed according to strategy (i.e. disparities between those scripts that were drafted and those that were translated) and 
work order (i.e. whether and how prior experience with script translation helped in drafting AD script from scratch).

Table 10. Unit 5 - practical tasks

\begin{tabular}{|l|l|}
\hline Activity 5.1 & $\begin{array}{l}\text { Individual work: Watch six short clips and read AD that was } \\
\text { prepared for them. Vote in an online poll on your preferred ver- } \\
\text { sion for each of the scenes. }\end{array}$ \\
\hline Activity 5.2 & $\begin{array}{l}\text { Discussion: Which of the two audio descriptions did you prefer } \\
\text { and why? Can you tell which ADs were translated from English } \\
\text { and which were originally drafted in Polish? }\end{array}$ \\
\hline Activity 5.3 & $\begin{array}{l}\text { Individual work: Prepare ADs for two short videos. Students } \\
\text { from Group 1 will draft the AD to Clip 1 and then translate the } \\
\text { AD to Clip 2. Students from Group 2 will first translate the AD } \\
\text { to Clip 2 and then draft the AD for Clip 1. }\end{array}$ \\
\hline Activity 5.4 & $\begin{array}{l}\text { Discussion: How are your scripts different: the ones you created } \\
\text { and the ones created by your classmates? Do you think that } \\
\text { translating an AD helped you to draft an AD? Do you think that } \\
\text { translation of AD scripts could be a valid strategy for creating } \\
\text { ADs? What advantages or disadvantages would it have? What } \\
\text { do you think it takes to be an AD translator? }\end{array}$ \\
\hline
\end{tabular}

\subsection{UNIT 6: Guidelines and standards}

In Unit 6 students were introduced to the complex issue of guidelines and standards of audio description. Although guidelines and standards are introduced and broadly discussed, the main aim of Unit 6 was to enable students to look at guidelines critically and to show them that although guidelines are very useful, they should be regarded as such and not as absolute rules since, just like in translation, the one and only ideal audio description does not exist.

Before the activities are explained, it is necessary to comment on the guidelines and standards since this is crucial for understanding the pedagogical approach taken. Different documents, that are most commonly called guidelines, were created during the early years of AD development. Those guidelines - although now criticized as non-evidence based [Fryer, 2010; Udo, Fels, 2011; Jankowska, 2015] - are widely available on the Internet. Because of this easy access they are broadly relied on, especially by those new to the field that are looking for guidance on how to prepare ADs. On the one hand, guidelines provide this valuable 
basic introduction but on the other, they can be confusing for novice describers since they are oftentimes contradictory. What is more, they very often present information not as guidelines but rather as commandments that need to be followed. Poland has followed the trend of creating AD guidelines. Two such documents are currently available: "Standardy tworzenia audiodeskrypcji do produkcji audiowizualnych" [Standards for creating audio description to audiovisual productions] [Szymańska, Strzymiński, 2010] and "Audiodeskrypcja - zasady tworzenia" [Audio description - rules for creation] [Żórawska et al., 2011]. Although their titles might suggest otherwise, neither of them is a result of a standardization procedure carried out by a regulatory body. They were both created by NGOs and both as a compilation of guidelines based on personal experience of their authors and information found in guidelines existing in other countries. What is important is that those two documents present two very different approaches to $\mathrm{AD}$ creation, especially to the issue of objectivity of the description. It can be generalized that at present, audio description in Poland is done according to either of those approaches.

Similarly to the previous units, basic theoretical notions in Unit 4. were introduced in lectures as well as in reading assignments followed by an online quiz.

Table 11. Unit 6 - theoretical introduction

\begin{tabular}{|l|l|}
\hline Unit 6 & Introduction to guidelines and standards. \\
\hline Lecture & Guidelines and standards - an introduction. \\
\hline Reading & $\begin{array}{l}\text { Bittner, H. (2012), "Audio description guidelines - a compari- } \\
\text { son", New Perspectives in Translation, 20, pp. 41-61. } \\
\text { Rai, S., Greening, J., Leen P. (2010), A Comparative Study of } \\
\text { Audio Description Guidelines Prevalent in Different Countries, } \\
\text { RNIB, London. }\end{array}$ \\
\hline Quiz & $\begin{array}{l}\text { Online multiple choice quiz based on the lecture and the reading } \\
\text { assignment. }\end{array}$ \\
\hline
\end{tabular}

In the second part of Unit 6 students autonomously explored the existing Polish guidelines and were encouraged to question them. In Activity 6.1 they were asked to watch two clips (ca. 30 minutes each) each with ADs created according to different guidelines. This was followed by (Activity 6.2) a discussion on students' preferences but also about 
the differences between the two descriptions. In Activity 6.3 students were asked to prepare a group multimedia presentation that compared approaches to selected issues presented in two Polish AD guidelines. Interestingly, but not entirely surprisingly, rather than a comparison, both presentations offered a compilation of the rules. Even though the guidelines were very often self-contradictory, students did not feel that they were in the position to question 'rules' and 'standards'. This is why an additional activity was proposed (Activity 4.4) in which students were asked to cross-analyse the fragments they watched in Activity 4.1 against the guidelines. Their findings were then discussed in Activity 4.5. This enabled the students to look critically both at the guidelines and the audio descriptions.

Table 12. Unit 6 - practical tasks

\begin{tabular}{|l|l|}
\hline Activity 6.1 & $\begin{array}{l}\text { Individual work: Please watch Clip 1 and Clip 2. Please pay } \\
\text { special attention to the use of language, syntax and metaphors. } \\
\text { Note the construction, order and content of the description. } \\
\text { Observe how gestures, emotions, characters, sounds and colours } \\
\text { are described. Think about the objectivity/subjectivity of the } \\
\text { descriptions. See if you can notice whether the audio describers } \\
\text { censored the descriptions in some way. }\end{array}$ \\
\hline Activity 6.2 & $\begin{array}{l}\text { Discussion: Which of the two audio descriptions did you prefer } \\
\text { and why? }\end{array}$ \\
\hline Activity 6.3 & $\begin{array}{l}\text { Group assignment: In this assignment you will work in groups } \\
\text { in order to prepare a multimedia presentation (ca. 15 minutes) } \\
\text { on Polish guidelines and standards on audio description. Each } \\
\text { group will compare different aspects of the guidelines. Group 1: } \\
\text { syntax, metaphors, character naming and description of physical } \\
\text { appearance, sounds, colours, objective vs subjective description. } \\
\text { Group 2: structure, order and content of description, gestures, } \\
\text { emotions and mimics, censorship, objective vs subjective } \\
\text { description. }\end{array}$ \\
\hline
\end{tabular}

\subsection{UNIT 7: Strategies for audio description}

Most guidelines advise audio description to be objective, however recent trends in AD research and practice question the 'objectivity paradigm' [Szarkowska, Jankowska, 2015] and point towards the use of strategies based on those known from Translation Studies [Chmiel, Mazur, 2014; 
Maszerowska, Matamala, Orero, 2014; Mazur, 2014; Remael, Reviers, Vercauteren, 2014; Jankowska, Szarkowska, 2016; Matamala, Orero, 2016]. Another interesting change in the approach to AD is the focus on its emotional rather than informative functions through the creative use of language [Fryer, Freeman, 2013, 2014; Szarkowska, Wasylczyk, 2014; Ramos Caro, 2015, 2016; Fryer, 2016; Walczak, 2017; Walczak, Fryer, 2017] or emotional voicing. Given all that, the main aim of Unit 7 was to equip students to use various strategies while creating an AD according to 'audio description brief', a concept borrowed from Translation Studies. Students were not discouraged from creating 'objective' descriptions but rather to 'work with a scale with subjective and objective at the two extremes and varying degrees of objectivity and subjectivity in between rather than with a binary opposition of objective versus subjective' [Mazur, Chmiel, 2012: 186].

In the theoretical introduction to Unit 7 students were familiarized with new approaches towards $\mathrm{AD}$ and saw how these new approaches can be applied in practice. As in other units, three types of activities were used: lecture, reading assignment and quiz.

Table 13. Unit 7 - theoretical introduction

\begin{tabular}{|l|l|}
\hline Unit 7 & Strategies in audio description. \\
\hline Lecture & Strategies and non-standard AD - and an overview. \\
\hline Reading & $\begin{array}{l}\text { Mazur, I. (2014), "Projekt adlab i funkcjonalizm w przekładzie } \\
- \text { w stronę strategii audiodeskrypcyjnych", Przektadaniec, 28, } \\
\text { pp. 11-22. }\end{array}$ \\
\hline Quiz & $\begin{array}{l}\text { Online multiple choice quiz based on the lecture and the reading } \\
\text { assignment. }\end{array}$ \\
\hline
\end{tabular}

In Activity 7.1 students were asked to see three very different descriptions of one scene. A discussion followed in order to find the most suitable AD for this particular scene, which surprisingly turned out to be the most objective of the descriptions. The scene was chosen purposefully to show students that even if one chooses non-objective AD as a global strategy, objective description can still be used as a local strategy. In Activity 7.2 students were asked to read two different descriptions of the same scene (both descriptions were manipulated to resemble 
the extremes of objectivity and subjectivity as closely as possible) and to write a short essay commenting on the solutions applied. After that they were asked to prepare a third version combining the solutions they liked most from both descriptions or provide their own. In Activity 7.3 students listened to two emotional clips (no image only soundtrack) with two different ADs: a creative one and a standard one. Then they saw the videos the ADs were prepared for. This served as a starting point in a discussion about the differences between the ADs but most of all the differences in the emotional load they both transmit and the different viewing experience of the sighted and visually impaired viewers.

Table 14. Unit 7 - practical tasks

\begin{tabular}{|l|l|}
\hline Activity 7.1 & $\begin{array}{l}\text { Discussion: Read three descriptions of the same scene. Which } \\
\text { one in your opinion suits the 'audio description brief' of this } \\
\text { scene and why? }\end{array}$ \\
\hline Activity 7.2 & $\begin{array}{l}\text { Individual work: Read two descriptions of the same scene. } \\
\text { Think what you did or did not like in each of them. Then pre- } \\
\text { pare your version and write 100-150 explaining your choices. }\end{array}$ \\
\hline Activity 7.3 & $\begin{array}{l}\text { Discussion: Listen to two clips with ADs. Then see the clips } \\
\text { they were prepared for. What emotions did you feel when listen- } \\
\text { ing to ADs? And when watching the clips? What do you think } \\
\text { the blind audiences would be missing out and why? What do } \\
\text { you think could be done to provide them with the same viewing } \\
\text { experience? }\end{array}$ \\
\hline
\end{tabular}

\subsection{Unit 8 - describing people}

Describing people is one of the most complex issues in audio description. It includes a vast array of aspects like introducing and naming the characters, describing their physical appearance (age, sex, race, characteristic features, costumes, etc.), relationship between them, emotions, gestures and mimics. In Unit 8 this complex issue was introduced and students were challenged with preparing descriptions of characters as well as with issues such as the structure of a description and the approach towards the naming of characters.

Basic information about character description was introduced in the theoretical introduction through lecture and reading assignment which were followed by a multiple choice quiz. 
Table 15. Unit 8 - theoretical introduction

\begin{tabular}{|l|l|}
\hline Unit 8 & Describing characters. \\
\hline Lecture & Describing characters - introduction. \\
\hline Reading & $\begin{array}{l}\text { Chmiel, A., Mazur, I. (2014), Audiodeskrypcja, Wydział } \\
\text { Anglistyki im. Adama Mickiewicza w Poznaniu, Poznan, } \\
\text { pp. 131-177. }\end{array}$ \\
\hline Quiz & $\begin{array}{l}\text { Online multiple choice quiz based on the lecture and the reading } \\
\text { assignment. }\end{array}$ \\
\hline
\end{tabular}

In the second part of the Unit students were involved in drafting descriptions of characters. Special attention was given to spatiotemporal limitations - one of the major constraints in AD. In Activity 8.1 students worked in groups to prepare ADs of a picture of a famous actor. There were 6 groups and 3 pictures (the same actor in three different situations) which means that two independent descriptions were prepared for each picture. After completing the descriptions, students were asked twice to shorten them by half in order to get used to the spatiotemporal constraints in $\mathrm{AD}$. The descriptions were then read aloud. It was also revealed that each of them portrayed the same person. This activity was followed by a discussion (Activity 8.2) in which students were asked to reflect upon these features which made given descriptions easier to understand. In Activity 8.3 students were asked to join with the group that had the same picture and create its final description - this was done so that students could practice accepting and offering feedback as well as negotiating. For the final assignment of the module students worked individually. They were asked to prepare ADs (Activity 8.4) for a short video (ca. 2 minutes) that was purposefully recorded in slow motion by its director. Once they completed this task they were asked to prepare $\mathrm{AD}$ for the same clip recorded in real time (ca. 10 seconds). The purpose of this activity was to give students an opportunity to work with time constraints but also to experiment with adapting description strategies to the director's creative vision. 
Table 16. Unit 8 - practical tasks

\begin{tabular}{|l|l|}
\hline Activity 8.1 & $\begin{array}{l}\text { Group/pair work: Prepare a description (ca. 100 words) of the } \\
\text { picture you were assigned. When you are done rewrite your } \\
\text { description so that it has ca. 50 words. Then rewrite it again so } \\
\text { that it has 25 words. }\end{array}$ \\
\hline Activity 8.2 & $\begin{array}{l}\text { Discussion: Were you able to guess from the descriptions that it } \\
\text { was the same actor? And from the pictures? Which descriptions } \\
\text { were easier to imagine and why? }\end{array}$ \\
\hline Activity 8.3 & $\begin{array}{l}\text { Group work: Work with your classmates to prepare a final de- } \\
\text { scription of the picture you were assigned (ca. 25 words). }\end{array}$ \\
\hline Activity 8.4 & $\begin{array}{l}\text { Individual work: Prepare an AD for Clip 1. Then prepare an } \\
\text { AD for Clip 2 (you will not be able to access Clip 2 unless you } \\
\text { submit an AD to Clip 1). }\end{array}$ \\
\hline
\end{tabular}

\subsection{Unit 9 - epilogue}

After the module was completed, students were offered to volunteer during the Film Music Festival in Krakow, where Titanic (dir. James Cameron, 1997) was screened with live music, audio description and audio subtitles. Out of 16 students who attended the module 9 were interested. They were involved in all stages of the AD production process (drafting, proofreading and quality control of the recording) as well as in aiding the visually impaired persons during the screening. Initial analysis from the in-depth interviews conducted with students show that they found this experience inspiring and they felt that they learned a lot.

\section{Assessment}

Assessment was one of the most challenging aspects of the module. While quizzes were set up in such way that they were graded automatically, the rest of the assignments needed to be evaluated manually. Although some assignments were peer reviewed, the majority still had to be reviewed and graded by the course tutor. This was a very time consuming task in which, I admit as the tutor, I have not always succeeded.

\section{Possible modifications}

Although the module was generally assessed positively (4.37 out of 5 in teaching quality assessment survey conducted by JU Section for 
Education Quality) there are at least four areas in which it could be improved. The first of them is regularity. When undertaking the task of teaching a module involving blended learning techniques, I did not realize that preparing an online module is much more time consuming and requires far more effort and planning than the face-to-face format. This is why the units were not always delivered on the same day and hour. Looking back - I think it is essential to keep them as regular as possible, they should ideally always be made available on the same day and hour. This enables both the students and the trainer to plan their tasks better. Secondly, I think that the module should have involved even more practical hands-on training activities in drafting ADs, since the best way to learn is through practice and one's mistakes. This should also include working on at least one entire film (e.g. short film or series episode). This is the only way for students to experience all the interconnected constraints of AD. However, more practical activities would mean even more time spent on assessment - the third area that needs improving. It is crucial for students to carry out as many AD drafting activities as possible, to receive feedback and to receive it without delay (i.e. before they move onto tasks that require skills trained in previous activities). On the other hand, the time needed for assessing students' performance should be somehow rationalized. The key to combine these two seemingly contradictory requirements could be to change the workflow:

a) Instead of correcting and commenting each assignment individually, a short presentation commenting on the most common issues (video recording) could be prepared.

b) Instead of asking each student to prepare ADs for one clip more assignments could be carried out in groups i.e. through crowdsourcing. This, on the one hand, would allow students to work on slightly longer clips and train team working skills. On the other hand, it would save the trainer from a monotonous assessment of the same material that very often contains the same mistakes.

Last but not least - in the future the scope of the module should be broader, as in my feeling, the incorporated units do not cover all the basic and essential skills a describer needs. This, however, requires more research and reflection on both the time available and students' workload. 


\section{Conclusions}

Teaching audio description in a module that involved blended learning techniques and relied mostly on on-line activities was an interesting adventure. However, as much as I am a fan of new technologies, I must say that I am not entirely convinced by this one. Much less now than I was at the beginning. Can it be efficient? Definitely yes. Can students learn as much as in the face-to-face format? Absolutely. Did I transmit the passion? I think I managed, but partially because I worked with students I have previously taught exclusively in the face-to-face format and it seemed we connected very well. I am not sure such a connection would be possible if we had not worked together before. Thus, a fifth area in which I would like to improve this module is finding a way of establishing a close relationship with students. This is essential if I am to transmit something more than just hard skills.

Why do I consider this aspect so important? With time I gained confidence that training audio describers is not only about knowledge, skills and competencies. There is one thing that should not be overlooked in audio describers' training. Orero [2005: 10] calls it "commitment to access for people with disabilities". I would like to make it more precise. I am strongly convinced that future audio describers should experience personal contact with blind or partially sighted AD users. There are two reasons for this. Firstly, this allows audio descriptions better suited for the target audience needs to be created. But there is another, a more egotistic, side to it. Audio description is not only a job. It is a service to the community. If performed well it can be like the non-zero-sum game, mutually beneficial. Giving people with visual disabilities access to culture, emotions and thrills at the same time gives the audio describers a luxury not many jobs offer: a sense of purpose.

\section{References}

Chaume Varela, F., (2012), Audiovisual Translation: Dubbing, St Jerome, Manchester.

Chmiel, A., Mazur, I. (2014), Audiodeskrypcja, Wydział Anglistyki Uniwersytetu im. Adama Mickiewicza, Poznań. 
Chmiel, A., Mazur, I. (2016), "Researching preferences of audio description users - limitations and solutions", Across Languages and Cultures, 17(2), 271-288.

Franco, E., Matamala, A., Orero, P. (2010), Voice-over Tanslation An Overview, Peter Lang, New York-Oxford-Wien.

Fryer, L. (2010), "Directing in Reverse", in: Kemble, I. (ed.), The Changing Face of Translation, Proceedings of the 9th Annual Portsmuth Translation Conference, University of Portsmouth, Portsmouth, 63-72.

Fryer, L. (2016), An introduction to Audio Description A Practical Guide, Routledge, London and New York.

Fryer, L., Freeman, J. (2013), "Cinematic language and the description of film: keeping AD users in the frame", Perspectives: Studies in Translatology, 21(3), 412-426.

Fryer, L., Freeman, J. (2014), “Can you feel what I'm saying? The impact of verbal information on emotion elicitation and presence in people with a visual impairment", in: Proceedings of the International Society for Presence Research, 99-107.

Jankowska, A. (2015), Translating Audio Description Scripts Translation as a New Strategy of Creating Audio Description, Peter Lang, Frankfurt am Main-Berlin-Bern-Bruxelles-New York-Oxford-Wien.

Jankowska, A., Szarkowska, A. (2016), "Strategie opisu kulturemów w audiodeskrypcji”, Między Oryginatem a Przektadem, 31, 136-152.

Jankowska, A., Zabrocka, M. (2016), "How Co-Speech Gestures are Rendered in Audio Description: A Case Study", in: Matamala, A., Orero, P. (eds.), Researching Audio Description. New Approaches, Palgrave Macmillan, London, 169-186.

Laurillard, B.D. (2012), Teaching as a Design Science, Routledge, New York and London.

Maszerowska, A., Matamala, A., Orero, P. (eds.) (2014), Audio Description. New perspectives illustrated, John Benjamins Publishing Company, Amsterdam, Benjamins Translation Library.

Matamala, A., Orero, P. (2007), "Designing a Course on Audio Description and Defining the Main Competences of the Future Professional", Linguistica Antverpiensia, New Series - Themes in Translation Studies, 6, 329-344.

Matamala, A., Orero, P. (eds.) (2016), Researching Audio Description. New Approaches, Palgrave Mcmillan, London. 
Matamala, A., Rami, N. (2009), "Análisis comparativo de las audiodescripciones española y alemana de 'Good-bye Lenin'", Hermēneus. Revista de Traducción e Interpretación, 11, 249-266.

Mazur, I. (2014), "Projekt adlab i funkcjonalizm w przekładzie - w stronę strategii audiodeskrypcyjnych", Przekładaniec, 28, 11-22.

Mazur, I., Chmiel, A. (2012), "Audio Description Made to Measure: Reflections on Interpretation in AD based on the Pear Tree Project Data", in: Audiovisual Translation and Media Accessibility at the Crossroads. Media for All 3, Rodopi, Amsterdam and New York, 173-188.

Orero, P. (2005), “Audio Description: Professional Recognition, Practice and Standards in Spain", Translation Watch Quarterly, 1, 7-18.

Orero-Clavero, M.P. (2012), “Audio Description Behaviour: Universals, Regularities and Guidelines", International Journal of Humanities and Social Science, 2(17), 195-202.

Ramos Caro, M. (2015), "The emotional experience of films: Does audio description make a difference?", Translator, 21(1), 68-94.

Ramos Caro, M. (2016), "Testing audio narration: the emotional impact of language in audio description", Perspectives, 24(4), 1-29.

Remael, A., Reviers, N., Vercauteren, G. (2014), ADLAB Audio Description guideline, [on-line] http://www.adlabproject.eu/Docs/adlab\%20book/index. html - 1.05.2017.

Remael, A., Vercauteren, G. (2007), "Audio describing the exposition phase of films. Teaching students what to choose", Trans. Revista de Traductologia, 11, 73-93.

Reviers, N. (2016), "Audio description services in Europe: an update", 26, 232-247.

Sadowska, A. (2014), “Audiodeskrypcja do ilustracji w prasie”, Przektadaniec, 28, 124-139.

Snyder, J. (2007), “Audio Description: The Visual Made Verbal”, The International Journal of the Arts in Society, 2, 99-104.

Snyder, J. (2014), The visual made verbal: a comprehensive training manual and guide to the history and applications of audio description, Dog Ear Publishing, Indianapolis.

Szarkowska, A., Jankowska, A. (2012), "Text-to-speech audio description of voiced-over films. A case study of audio described Volver in Polish", in: Perego, E. (ed.), Emerging topics in translation: Audio description, EUT Edizioni Università di Trieste, Trieste, 81-98. 
Szarkowska, A., Jankowska, A. (2015), “Audio describing foreign films”, The Journal of Specialised Translation, 23, 243-269.

Szarkowska, A., Wasylczyk, P. (2014), “Audiodeskrypcja Autorska”, Przektadaniec, 28, 48-62.

Szymańska, B., Strzymiński, T. (2010), "Standardy tworzenia audiodeskrypcji do produkcji audiowizualnych", [on-line] http://avt.ils.uw.edu.pl/ files/2010/12/AD__standardy_tworzenia.pdf - 1.05.2017.

Udo, J.P., Fels, D.I. (2011), "From the describer's mouth: Reflections on creating unconventional audio description for live theatre", in: Şerban, A., Matamala, A., Lavaur, J.-M. (eds.), Audiovisual Translation in Close-up, Peter Lang, Bern-Berlin-Bruxelles-Frankfurt am Main-New York-Oxford-Wien, 257-278.

Utray, F., Pereira, A.M. Orero, P. (2009), "The Present and Future of Audio Description and Subtitling for the Deaf and Hard of Hearing in Spain", Meta: journal des traducteurs / Meta: Translators'Journal, 54(2), 248-263.

Walczak, A. (2017), Immersion in audio description. The impact of style and vocal delivery on users' experience, Universitat Autònoma de Barcelona, Barcelona.

Walczak, A., Fryer, L. (2017), "Creative description: The impact of audio description style on presence in visually impaired audiences", British Journal of Visual Impairment, 35(1), 6-17.

Żórawska, A., Więckowski, R., Kunstler, I., Butkowska, U. (2011), "Audiodeskrypcja - zasady tworzenia", [on-line] http://dzieciom.pl/wp-content/ uploads/2012/09/Audiodeskrypcja-zasady-tworzenia.pdf. - 02.05.2017.

\section{STREsZCZENIE}

\section{Blended learning w kształceniu audiodeskryptorów}

Artykuł prezentuje i omawia kurs z zakresu audiodeskrypcji, który autorka artykułu prowadziła w roku akademickim 2016/2017 w Katedrze do Badań nad Przekładem i Komunikacją Międzykulturową (Uniwersytet Jagielloński w Krakowie) w trybie blended learning.

Słowa kluczowe: audiodeskrypcja, dydaktyka, blended learning 
SUMMARY

This article is a practice report that discusses the course in audio description that was taught by the author of the articles in 2016/2017 at the Chair for Translation Studies and Intercultural Communication at the Jagiellonian University in Krakow by means of blended learning.

Key words: audio description, accessibility, didactics, blended learning 